\title{
"Mind the Gaps": Hidden Purposes and Missing Internationalism in Scholarship on the Rhetoric of Science and Technology in Public Discourse
}

\author{
Celeste M. Condit
}

Department of Communication Studies, University of Georgia

Athens, GA USA

Poroi 9,1 (April 2013)

Travelers using transit systems in cities such as London, Hong Kong, Singapore, New Delhi, Athens, or Beijing will be familiar with the phrase "Mind the Gap"-a warning about spaces where moving vehicles and fixed platforms leave holes to trap the unwary. In this brief space, I will point out two scholarly gaps in the Association for the Rhetoric of Science and Technology (ARST) research corpus and suggest a way in which attending to each may illuminate the other. The first and probably most contentious gap I allege is a lack of sufficient collective reflectiveness about our purposes in studying "rhetorics of science and technology" (my focus is especially in public discourse venues, although similar problems arise in the broader range of rhetoric of science and technology [RST] work). The second gap I will point to is the Euro-American-centrism of most work done in this community. The relatively few published studies with an international focus indicate that great promise lies in expanding the RST repertoire in that direction, and I see some evidence that doing so may also aid those who wish to become more sophisticated about the purposes for RST work. In addition, the globalization of science along with everything else suggests that it is well past time to do much more of that kind of hard work.

\section{Stumbling into the Gap(s)}

In 2012, John Lynch and I conducted a review of studies published in academic journals between 1994 and 2012 that focused on the rhetorics of science and technology as they appear in public discourse. We argued (Condit \& Lynch, 2012) that scholars had appeared to pursue four purposes in their work. The present argument is based on that taxonomy, but I'm solely responsible for this extension. The least common category we found, and probably the least controversial given the goals of academe, was constituted by essays dedicated to theory-building (e.g., Constantinides, 2001; Keränen, 2005; Lynch, 2009; McClure, 2009; Tillery, 2003). The other three purposes were potentially in conflict with each other to various degrees, and the tensions should be attended to, given the larger movements in the socio-political world, as well as given 
the high profile arguments currently being made about the relationships among the humanities, social sciences, and biological sciences.

The most common purpose we identified in this set of essays was to challenge specific representations associated with science. Such studies generally identified biases or showed how science as represented in the public realm served oppressive interests, but they exhibited a range of scope with regard to the level at which their criticism was directed. Some of these essays appear to take a stance of radical opposition to science per se (Bass, 1998; Happe, 2006a,b; Johnson, 2004, 2006, 2008; Mechling \& Mechling, 1995; Scott, 2002) and others might be read merely as knocking some of the stuffing out of science's self-appraisal (Lessl, 1999), while others seem more narrowly focused, directed to errors in a particular set of scientific assertions, but not articulating a broader condemnation of science per se (Koerber et al., 2008). The former end of the spectrum might be labeled "science bad" studies and the latter "bad science" studies.

A second highly common purpose consisted of explorations of the relative influence of science on public policies (hereafter "the power of science" studies). Although most such studies assumed science was too powerful and were directed at increasing the role of the public in science policy and related realms, there was again some range in the relationship they projected between the rhetorical critic and science. Some were quite antagonistic (i.e. "science too powerful"; e.g., Bennett, 2008; Endres, 2009), others were apparently more melioristic (Evans et al., 2009), and still others seemed to suggest that science was already at least partially a subject of, rather than a powerful lord over, public discourse (Jordan, 2004, 2009; Ratto, 2006).

The oppositional stance of the "science bad" and "science too powerful" studies seems to be at odds with a third, relatively uncommon but apparently growing set of studies, the "Isocratean" studies that offered to improve scientific rhetorics (e.g., Ceccarelli, 2011; Jensen, 2007; Park, 2001; Spoel et al., 2009; Väliverronen and Hellsten, 2002). Instead of assuming that science was inherently or at least seriously flawed in its assumptions or conclusions, or that science was too powerful in the force it exerted in public, these essays assumed that scientists needed a little bit of help conveying their message to the public, and by implication that the world would be better with a little more scientific influence (at least of some kinds) rather than less.

In all of these categories, most of the essays took for granted the validity of the purpose of their study, rather than reflecting upon it. In the related and overlapping fields of "STS" (Science and Technology Studies), there has been some intense debate over purpose, but that debate is not evident in rhetorical studies. Perhaps our far-flung and thinly staffed academic interest area survives best by papering over such fundamental differences in the purposes of our shared work. If we agree to disagree about just why we are doing what we are doing, we have a bigger tent. But I'm no longer comfortable with this pseudo-harmony, because of broader forces I will sketch shortly. So, at the risk of stirring up unproductive acrimony, I think we should attend to this question. 


\section{The Enemy Is Digging the Gap to Undermine Us}

I pick this moment to raise this question because I believe that there is a newly powerful array of social forces and alliances to which any astute rhetorician should attend. These forces seek to destroy the ability of any of us to do what we see as constructive academic work. In the face of that threat, there is a "better for now" stance for scholars in the rhetoric of science and technology to take. Whether you agree with my idea of what is "better for now" or not, I suggest you ought to attend to those forces in some way.

The enemy on the horizon is not science, but what I have elsewhere called political regressives and will now just call the warlord cast. Yes, "warlord" seems a bit over-the-top rhetorically, but it is a succinct shorthand for what is at stake. Political regressives are arguing to eviscerate what we have come to know as the large-scale state in order to expand their personal power. They're actually shockingly overt about those goals, referring casually to their desire to build "dynasties." They, like every feudal lord in history, recognize that a liberal democratic state limits their own power. These individuals are not aligned with "science"though they may use science as a strategic tool, just as they sometimes use religion, rhetoric, and the fine arts as strategic tools (think Koch's devotion to ballet!). To achieve their dynastic ambitions, the destruction of public universities and the control of private universities is appropriately high on their targeting lists. While they are willing to selectively deploy the products of the university for their personal power, they are not willing to countenance centers of innovation that are not tightly under their power (it's okay to have business schools and pharmaceutical labs, but not evolution or sociology!).

Maintaining a university life-world that has its own integrity seems crucial to resisting these forces. And indeed, the existence of something like universities as special networked communities played a substantial role in overcoming the original version of Western feudalism. Such a perspective urges one to see the humanities, the natural sciences, and the social sciences not as supra-disciplinary competitors, but as mutual contributors to a cosmopolitan and globalizing perspective that continues to work against concentrations of lordly power. The tendencies of these three supra-disciplines, each in their own way, to expand the breadth of vision, self control, and empathy of young people have been productive contributors to the decline in violence, torture, ethnocentrism, rape, domestic abuse, and child abuse that, according to Steven Pinker's (2011) nuanced documentation, occurred between 1400 and 2000. Further progress is desirable and urgent, and in contrast to what Pinker suggests, further progress may require additional approaches. But we should not spend all our time looking for additional approaches while the enemy of the approaches that have worked to a notable degree destroys our capacity to explore at all in an academic mode. That is, the oppositional emotions of rhetoricians should not currently be directed primarily at scientists.

This assertion (or call to re-orientation) depends on what Bruce Railsback and I have called (in reply to E.O. Wilson) a transilient 
perspective (Condit \& Railsback, 2005). The transilient perspective notices both continuities and discontinuities among the humanities, natural sciences, and social sciences, and calls for an appreciation of both of those dimensions. As a rhetorician examining science, I have been maintaining for quite some time that scientists cannot achieve what they claim to want to achieve-maximally inter-subjective, trans-situational descriptions-unless they are also self-reflective about the role of language in their endeavors. Rhetorical reflection should therefore be part of the scientific method (or rather, part of the supra-methodology of expanding understanding). But equally, I have become discouraged with my rhetorical colleagues who time and again portray science as an evil enemy, rule out the use of social scientific research in rhetorical essays, or refuse to be held accountable for the impressive and important bodies of evidence that natural and social scientists have amassed. I am not suggesting that we should stop doing "bad science" studies, or contesting places where science exercises lop-sided influence, but I am suggesting that the predominance of "science bad" studies is ill-considered and probably disadvantageous to our own interests, as well as those of humanity more generally.

To be an academic should not mean to find the narrowest possible community to credit or gain accreditation with. It should be to accept the mission of enhancing understanding, where understanding engages maximal possible breadth under the-necessarily and desirably vaguetrajectory of improving the richness of life for human beings while protecting the natural world around us. Scientists cannot expand understanding in this way without the humanities, social scientists cannot do this without the humanities, and humanists (or post-humanists) like rhetoricians also can't do this without the natural and social scientists. Perhaps the warlords want to set the clock back to the pre-scientific era, but I am willing to argue-at as much length as necessary-that anyone who is not focused on their own status drives cannot read the available evidence and maintain that the world would be better if all the scientists walked out of their laboratories and turned into rhetorical critics overnight.

\section{An Academic Route: Internationalization}

I've offered a potentially divisive polemic. But rather than leaving it there, with only the alternative of engaging each other on a polemical basis, I want to offer a respectable academic route for achieving the selfreflectiveness about purposes that underlies my concern. I ran across this possibility while doing the survey with Lynch. In reading the dozens of studies we examined for our review, I was struck by how the few studies that took an international bent tended to be forced out of the too-easy stances of "science bad" or "science too powerful."

One fine example is Paroske's (2009) study of the rhetoric involved in the perspective that HIV does not cause AIDS as forwarded by former South African President Thabo Mbeki. Using both close textual analysis and attention to the multiplicity of contexts, Paroske's essay argues that Mbeki's early rhetoric can be understood as arising from the historical context of previous Western imperialism, but that it initially aligned with 
the view of science as an activity that involves the full and fair consideration of evidence as the basis for making claims. However, Paroske suggests that as time passed Mbeki's rhetoric changed, becoming something more akin to simple strategies for individual power maintenance. That summary does not do justice to the nuances of Paroske's argument, but I hope it shows how that analysis avoids the always-present trap for rhetoric of science studies-the temptation to offer a totalizing judgment that condemns and therefore urges the audience to reject an opponent (science) rather than to understand a rhetoric (and therefore to learn from it in a diversity of ways).

I suggest that the work by Xiao $(1995,2004)$ similarly provides novel insight, as it examines how Darwinist discourse was taken up in China, with its long-standing and distinctive cultural assumptions. Xiao's studies make clear that one cannot presume a singular model of sciencesociety interaction, or even a singularity to a given scientific "theory."

As valuable as these internationally focused studies are, there are precious few of them. And this paucity is particularly fascinating because many of the science controversies that scholars have studied have global reach. Thus, there are several studies of global warming (Besel, 2011; Foust \& Murphy, 2009; Moore, 2009; Spoel et al., 2009), but they tend not to engage the issue of the ways in which the associated rhetorics (pro, con, other) play out in non-Western contexts. An occasional mention of the different interests of industrialized and industrializing countries does not provide the richness of analysis and understanding that would seem to be available if one actually attended to the way in which "climate change" was discussed in the various regions of the globe. In the absence of self-awareness about globalization, there seems to be a universalization of U.S., or at best, "Western" rhetorics.

This internationalism-blind approach may have been encouraged by the tendency of early "rhetoric of science" studies to focus on a narrow "scientific" audience that could be presumed to be European (and eventually Euro-American). While that approach can be defended in terms of the original contexts of the research, Xiao's work has shown that even the "scientific" audience is not homogeneous as science has traveled the globe. In the face of that example, those who wish to maintain that science is universal now must do the research to demonstrate their claim, rather than merely postulating such universalism. Moreover, the interfaces between scientific communities and public policy seem even more likely to vary when cultural assumptions and governing structures are different. For example, Darwinism may play differently in public life not only in China, but also in India, where the role of science in society might be described as elegantly opportunist, perhaps as fostered by religions that do not demand univocality in public life.

Genetics has recently provided a major area of focus for science studies, and the tensions are evident here as well. The overwhelming majority of the articles Lynch and I located that discussed public scientific rhetorics about genetics took the national or global context for granted, and these contexts were Euro-American. One probably should call this "pseudo-universalization." I am not criticizing others here, but calling all 
of us to different orientations, for my own work, and that of my students, has attended almost exclusively to the U.S. (Condit, 2009; Gronnvoll \& Landau, 2010). My call to internationalization has been energized by what I have heard in attendance at international conferences, where people other than rhetoricians speak. The lively European work comparing public opinions about genetics, or the structuration of genetic establishments in different European countries, gives one a whiff of the possibilities. But a stark presentation by a scholar who had studied the role of genetics in Mexico and Columbia made it evident to me that we have an enormous amount to learn about how rhetorics about genetics can be deployed (Schwartz Marin, 2012). What happens when genetics is deployed in relationship to nationalistically developing cultures who codify mestizo identities? Or within a small, isolated, rural community where Huntington's chorea is common? Or where a developing nation sees the possibility that its native population's DNA might be one resource for moving the nation to the global stage?

It is not merely that we know too little because we only know our own context. It is also that we might be encouraged to be something like rhetorical determinists about science, settling too quickly for a narrow range of stories about how science and rhetoric must go or should go. In other words, the stories we tell may be wrong in important ways, because they mistake a fragment for a broader terrain. Because the rhetorics of science have power in the world, and because Euro-America is not the sole influence on the world-not even the sole source of science in the world-expanding our stories seems requisite if we believe that our story telling matters as understanding.

The ethnocentric focus of ARST scholars to this point has been quite understandable-we are a very small group of scholars, with pitiable resources compared to many academic areas. The task of addressing globalized rhetorics is extremely difficult; it demands multi-linguistic competence, international partnerships, expensive fieldwork, and widely open minds joined with careful, dogged, systematic efforts. All of this, however, may be just what we need to break up our too-comfortable assumptions about what "our" relationship to "science" should be, and to cause us to reflect on "our" purposes in doing academic work about science and technology.

The bright glimmers of existing internationalized work provide an important warning and promise. Mind the gaps!

\section{References}

Bass, J. (1998). Hearts of darkness and hot zones: The ideologeme of imperial contagion in recent accounts of viral outbreaks. Quarterly Journal of Speech, 84, 430-447.

Bennett, J. A. (2008). Passing, protesting, and the arts of resistance: Infiltrating the ritual space of blood donation. Quarterly Journal of Speech, 94, 23-43.

Besel, R. D. (2011). Opening the "black box" of climate change science: Actor-network theory and rhetorical practice in scientific 
controversies. Southern Communication Journal, 76, 120-136.

Ceccarelli, L. (2011). Manufactured scientific controversy: Science, rhetoric, and debate. Rhetoric \& Public Affairs, 14, 195-222.

Condit, C. M. (2009). Dynamic feelings about metaphors for genes: Implications for research and genetic policy. Genomics, Society and Policy, 5, 44-58.

Condit, C. M., \& Lynch, J. (2012). Recent rhetorical studies in public understanding of science: Multiple purposes and strengths. Public Understanding of Science, 21, 386-400.

Condit, C. M., \& Railsback, L. B. (2005). The Transilience Project. Transilience. Accessed March 10, 2013. http://www.gly.uga.edu/railsback/ Transilience/Transilience.html

Constantinides, H. (2001). The duality of scientific ethos: Deep and surface structures. Quarterly Journal of Speech, 87, 61-72.

Endres, D. (2009). The rhetoric of nuclear colonialism: Rhetorical exclusion of American Indian arguments in the Yucca Mountain nuclear waste siting decision. Communication and Critical/Cultural Studies, 6, 39-60.

Foust, C. R., \& Murphy, W. O. (2009). Revealing and reframing apocalyptic tragedy in global warming discourse. Environmental Communication, 3, 151-167.

Evans, R., Kotchetkova, I., \& Langer, S. (2009). Just around the corner: Rhetorics of progress and promise in genetic research. Public Understanding of Science, 18, 43-59.

Gronnvoll, M., \& Landau, J. (2010). From viruses to Russian roulette to dance: A rhetorical critique and creation of genetic metaphors. $R S Q$ : Rhetoric Society Quarterly, 40, 46-70.

Happe, K. E. (2006a). Heredity, gender and the discourse of ovarian cancer. New Genetics and Society, 25, 171-196.

----. (2006b). The rhetoric of race in breast cancer research. Patterns of Prejudice, 40, 461-480.

Jensen, R. E. (2007). Using science to argue for sexual education in U.S. Public Schools. Science Communication, 29, 217-241.

Johnson, D. (2004). Selling Sarafem: Priestly and bardic discourses in the construction of premenstrual syndrome. Women's Studies in Communication, 27, 331-351.

----. (2006). Dawkins' myth: The religious dominance of evolutionary discourse. Journal of Communication and Religion, 29, 285-314.

----. (2008). Psychiatric power: The post-museum as a site of rhetorical alignment. Communication \& Critical/Cultural Studies, 5, 344-362.

Jordan, J. W. (2004). The rhetorical limits of the "plastic body." Quarterly Journal of Speech, 90, 327-58.

----. (2009). Reshaping the "pillow angel”: Plastic bodies and the rhetoric

Celeste M. Condit

Poroi 9,1 (April 2013) 
of normal surgical solutions. Quarterly Journal of Speech, 95, 20-42.

Keränen, L. (2005). Mapping misconduct: Demarcating legitimate science from "fraud" in the B-06 lumpectomy controversy. Argumentation and Advocacy, 42, 94-113.

Koerber, A., Arnett, E. J., and Cumbie, T. (2008). Distortion and the politics of pain relief. Journal of Business and Technical Communication, 22, 364-391.

Lessl, T. M. (1999). The Galileo legend as scientific folklore. Quarterly Journal of Speech, 85, 146-168.

Lynch, J. A. (2009). Articulating scientific practice: Understanding Dean Hamer's "gay gene" study as overlapping material, social, and rhetorical registers. Quarterly Journal of Speech, 95, 435-456.

McClure, K. (2009). Resurrecting the narrative paradigm: Identification and the case of young earth creationism. Rhetoric Society Quarterly, 39, 189-211.

Mechling, E. W., and Mechling, J. (1995). The atom according to Disney. Quarterly Journal of Speech, 81, 436-53.

Moore, M. P. (2009). The Union of Concerned Scientists on the uncertainty of climate change: A study of synecdochic form. Environmental Communication, 3, 191-205.

Park, H. J. (2001). The creation-evolution debate: Carving creationism in the public mind. Public Understanding of Science, 1O, 173-186.

Paroske, M. (2009). Deliberating international science policy controversies: Uncertainty and AIDS in South Africa. Quarterly Journal of Speech, 95, 148-170.

Pinker, S. (2011). The better angels of our nature: Why violence has declined. New York, NY: Viking.

Ratto, M. (2006). Foundations and profiles: Splicing metaphors in genetic databases and biobanks. Public Understanding of Science, 15, 31-53.

Schwartz Marin, E. (2012, April 24). Postcolonial biopolitics and biocolonialism: Governance and the protection of 'genetic identities' in Mexico and Colombia. Paper Presented at "Genomics in Society: Facts, Fictions \& Cultures.” London, England.

Scott, J. B. (2002). The public policy debate over newborn HIV testing: A case study of the knowledge enthymeme. Rhetoric Society Quarterly, $32,57-84$.

Spoel, P., Goforth, D., Cheu, H., and Pearson, D. (2009). Public communication of climate change science: Engaging citizens through apocalyptic narrative explanation. Technical Communication Quarterly, 18, 49-81.

Tillery, D. (2003). Radioactive waste and technical doubts: Genre and environmental opposition to nuclear waste sites. Technical Communication Quarterly, 12, 405-421. 
Väliverronen, E. and Hellsten, I. (2002). From "burning library" to "green medicine": The role of metaphors in communicating biodiversity. Science Communication, 24, 229-45.

Xiao, X. (1995). China encounters Darwinism: A case of intercultural rhetoric. Quarterly Journal of Speech, 81, 83-99.

----. (2004). The 1923 scientistic campaign and Dao-discourse: A crosscultural study of the rhetoric of science. Quarterly Journal of Speech, 9o, 469-492. 